\title{
Investigation on Cell Surface Markers of Dental Pulp Stem Cell Isolated from Impacted Third Molar Based on International Society for Cellular Therapy Proposed Mesenchymal Stem Cell Markers
}

\author{
Ferry Sandra ${ }^{1}$, Janti Sudiono², Yohanna Feter ${ }^{3}$, Nadhia Sari Afiana ${ }^{3}$, Jessica Nathalia Chandra ${ }^{3}$, \\ Kharima Abdullah ${ }^{3}$, Jasmine Shafira ${ }^{3}$, Angliana Chouw ${ }^{4}$ \\ ${ }^{1}$ Department of Biochemistry and Molecular Biology, Division of Oral Biology, Faculty of Dentistry, Universitas Trisakti, \\ Jakarta, Indonesia \\ ${ }^{2}$ Department of Oral Pathology, Division of Oral Biology, Faculty of Dentistry, Universitas Trisakti, Jakarta, Indonesia \\ ${ }^{3}$ Faculty of Dentistry, Universitas Trisakti, Jakarta, Indonesia \\ ${ }^{4}$ Prodia Stemcell Indonesia, Jl. Kramat VII No.11, Jakarta, Indonesia
}

Background: Recently we have isolated and cultured dental pulp stem cell (DPSC) derived from impacted third molar (DPSC-M3). The DPSC-M3 was suggested as mesenchymal stem cell, however the cell surface markers were not completely clarified. Therefore current study was conducted to investigate the markers.

Materials and Methods: Passage 5 DPSC-M3 was cultured, labeled and examined with flow cytometer. All markers were investigated according to the proposed cell surface marker panel for the minimal identification of human mesenchymal stem cell (MSC) by International Society for Cellular Therapy (ISCT). The positive markers were cluster of differentiation (CD)90, CD73, CD105, while the negative markers were CD34, CD45, CD11b, CD19, and Human Leukocyte Antigen (HLA)-DR. Results: Results showed that the size and granularity of DPSC-M3 were ranged from 75 to 230 and 27 to 203, respectively. The cell surface antigens examination showed that CD90, CD105 and CD73 were highly expressed (>95\%), meanwhile expressions of CD45, CD34, CD11b, CD19 and HLA-DR were $<2 \%$.

Conclusion: Since the all markers expression were in accordance to the proposed cell surface marker panel for the minimal identification of human MSC by ISCT, DPSC-M3 could be suggested as an MSC.

Keywords: dental pulp, stem cell, dental pulp stem cell, ISCT, flow cytometry

\section{Introduction}

Stem cells are believed to be a potential alternative to repair tissue damage in the concept of regeneration. ${ }^{1-3}$ The role of stem cell became significant after the discovery of mesenchymal stem cell (MSC). ${ }^{3,4}$ MSC has a high capacity of proliferation, differentiation, and regeneration ${ }^{6,7}$. In addition, MSC has useful characteristics in cellular therapy

Date of submission: July 8, 2018

Last Revised: July 31, 2018

Accepted for publication: August 2, 2018

Corresponding Author:

Ferry Sandra

Department of Biochemistry and Molecular Biology, Division of Oral Biology

Faculty of Dentistry, Trisakti University, Jl. Kyai Tapa No.260

Jakarta, Indonesia

E-mail: ferrysandra@gmail.com

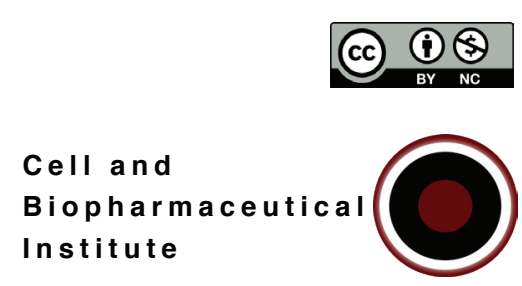


such as hypo-immunogenic and ability to avoid the allogenic rejection. ${ }^{8}$ MSC population can be found in body organs and tissues such as adipose tissue ${ }^{9}$, umbilical cord blood ${ }^{10}$, bone marrow ${ }^{11}$, and dental tissue ${ }^{12}$. Dental stem cells can be obtained easily and has showed its capacity to heal and regenerate dental tissues., ${ }^{4}$

Previous studies have reported on isolated human dental stem cells, and among the stem cells, dental pulp stem cell (DPSC) is commonly used in stem cells research. ${ }^{14}$ DPSC showed differentiation potency in which it can differentiate into adipocyte, odontoblast, chondrocyte, myoblast, and neurogenic cells. ${ }^{15,16}$ Some cell surface antigens of DPSC detected by immunohistochemistry are cluster of differentiation (CD)73, CD90, CD49, CD51, CD61, CD166/ALCAM, CD105, CD146, CD106, CD44, CD9, CD10 CD13, CD59, and CD271. ${ }^{17-19}$ In order for scientists to be able to identify the MSC and compare their studies, International Society for Cellular Therapy (ISCT) has proposed three specific criteria to define MSC. Among the criteria, there are positive (CD73, CD90, and CD105) and negative (CD45, CD34, CD11b, CD19 and Human Leukocyte Antigen (HLA)-DR) expressions of specific surface antigens, detected using flow cytometry. ${ }^{20}$

Recently, DPSC was isolated from impacted third molar (DPSC-M3). ${ }^{21}$ The DPSC-M3 was reported to express CD117, one of the stem cell marker, and to have an osteogenic potential. The DPSC-M3 were plastic adherent as well, suggesting that the DPSC-M3 might be having the MSC property. Therefore current study was conducted to investigate the cell surface marker of DPSC-M3 according to ISCT criteria.

\section{Materials and methods}

\section{DPSC-M3 thawing and cultures}

Previously reported cryopreserved passage 5 DPSC-M3 was thawed and cultured in Dulbecco's modified Eagle's medium (Gibco, Grand Island, NY, USA) supplemented with fetal bovine serum (Gibco) and amphotericin, penicillin, streptomycin (Gibco). ${ }^{21}$ Cultured DPSC-M3 was then subjected into flow cytometric analysis.

\section{Flow cytometric analysis}

Flow cytometric analysis was performed using BD Stemflow hMSC Analysis Kit (BD Biosciences, Franklin Lakes, NJ, USA). The panel in this kit was made according to the proposed cell surface marker panel for the minimal identification of human MSC by ISCT. ${ }^{20}$ Briefly, $1 \times 10^{7}$
DPSC-M3 were labeled with/without antibodies and their isotypes for positive markers of CD90, CD73, CD105, and negative markers of CD34, CD45, CD11b, CD19, and HLA-DR. For positive markers, the antibodies were fluorescein isothiocyanate (FITC)-conjugated mouse antihuman CD90 (Clone: 5E10), peridinin chlorophyll protein (PerCP)-cyanine (Cy)5.5-conjugated mouse anti-human CD105 (Clone: 266) and Alkaline Phosphatase Conjugate (APC)-conjugated mouse anti-human CD73 (Clone: AD2). The positive isotype antibodies were FITC-conjugated mouse anti-human IgG1 $\kappa$ (Clone: X40), PerCP- Cy5.5conjugated mouse anti-human IgG1 $\kappa($ Clone: $\mathrm{X} 40)$ and APC-conjugated mouse anti-human IgG1 $\kappa$ (Clone: X40). Meanwhile for negative markers, all antibodies were conjugated with phycoerythrin (PE) (PE-conjugated CD45 (Clone: HI30), PE-conjugated CD34 (Clone: 581), PEconjugated CD11b (Clone: ICRF44), PE-conjugated CD19 (Clone: HIB19) and PE-conjugated HLA-DR antibodies (Clone: G46-6). The negative isotype antibodies were PEconjugated mouse anti-human IgG1 $\kappa$ (Clone: X40), PEconjugated mouse anti-human IgG2a $\kappa$ and PE-conjugated mouse anti-human IgG2b $\kappa$ (Clone: G155-178). Individual positive controls are included for compensation set-up in the kit. The labeled-cells were then loaded into FACSCanto II (BD) and analyzed with FACSDiva software (BD).

\section{Results}

\section{Size and granularity of DPSC-M3}

The FSC for size and the SSC for granularity of DPSC-M3 are shown in dot plot (Figure 1). The size and granularity of DPSC-M3 were ranged from 75 to 230 and 27 to 203, respectively.

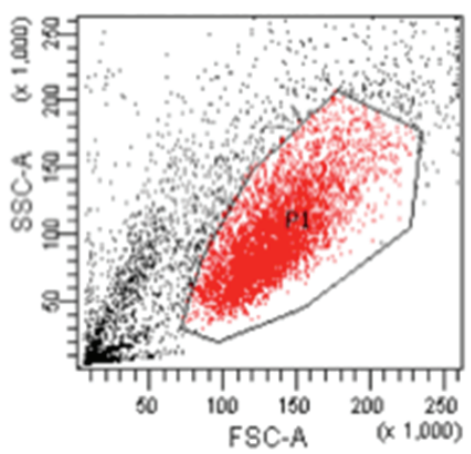

Figure 1. The size and granularity of DPSC-M3. DPSC-M3 in passage 5 was harvested and analyzed using FACSCanto for FSC and SSC. FSC and SSC of DPSC-M3 were examined three times. 


\section{DPSC-M3 surface marker expression}

The dot plot results of unlabeled and isotype antibodieslabeled DPSC-M3 for negative markers and CD90, showed that the cells were located in Q3 areas (Figure 2A1a and $2 \mathrm{~A} 1 \mathrm{~b})$ with the percentage ranging from 98.6 to $99 \%$ for unlabeled DPSC-M3 and from 87.8 to $98 \%$ for isotype antibodies-labeled DPSC-M3 (Table 1). The dot plot results of antibodies-labeled DPSC-M3 showed that the cells were located in Q4 areas (Figure 2A1c) with the percentage ranging from $99.1-99.6 \%$ (Table 1 ).

The histogram results of unlabeled, isotype antibodieslabeled and antibodies-labeled DPSC-M3 for negative markers are shown in Figure 2A2a, 2A2b and 2A2c, respectively. The percentages of histogram results for the negative markers, located in $\mathrm{P} 3$ areas, were ranging from 0 to $0.1 \%$ for unlabeled DPSC-M3, from 0.1 to $0.3 \%$ for isotype antibodies-labeled DPSC-M3 and from 0 to $0.1 \%$ for antibodies-labeled DPSC-M3 (Table 1). Meanwhile, the histogram results of unlabeled, isotype antibodieslabeled and antibodies-labeled DPSC-M3 for CD90 are shown in Figure 2A3a, 2A3b, and $2 \mathrm{~A} 3 \mathrm{c}$, respectively. The percentages of histogram results for CD90, located in P2 areas, were ranging from 0.3 to $0.5 \%$ for unlabeled DPSC-M3, from 0.4 to $0.6 \%$ for isotype antibodies-labeled DPSC-M3 and from 97 to $97.2 \%$ for antibodies-labeled DPSC-M3 (Table 1).

The dot plot results of unlabeled and isotype antibodies-labeled DPSC-M3 for CD73 and CD105, showed that the cells were located in Q3-1 areas (Figure $2 \mathrm{~B} 1 \mathrm{a}$ and $2 \mathrm{~B} 1 \mathrm{~b}$ ) with the percentage ranging from 99.4 to $99.7 \%$ for unlabeled DPSC-M3 and from 98.1 to $99 \%$ for isotype antibodies-labeled DPSC-M3 (Table 2). The dot plot results of antibodies-labeled DPSC-M3 showed that the cells were located in Q2-1 areas (Figure 2B1c) with the percentage ranging from 99.7 to $100 \%$ (Table 2).

The histogram results of unlabeled, isotype antibodieslabeled and antibodies-labeled DPSC-M3 for CD73 are shown in Figure 2B2a, 2B2b and 2B2c, respectively. The percentages of histogram results for the $\mathrm{CD} 73$, located in P5 areas, were 0 for unlabeled DPSC-M3, ranging from 0.1 to $0.4 \%$ for isotype antibodies-labeled DPSC-M3 and from 98.7 to $99.2 \%$ for antibodies-labeled DPSC-M3 (Table 2). Meanwhile, the histogram results of unlabeled, isotype antibodies-labeled and antibodies-labeled DPSC-M3 for CD105 are shown in Figure 2B3a, 2B3b, and 2B3c, respectively. The percentages of histogram results for $\mathrm{CD} 105$, located in $\mathrm{P} 4$ areas, were ranging from 0.4 to $0.8 \%$ for unlabeled DPSC-M3, from 1.6 to $1.9 \%$ for isotype antibodies-labeled DPSC-M3 and from 97 to $98.8 \%$ for antibodies-labeled DPSC-M3 (Table 2).

\section{Discussion}

The results showed that sizes of DPSC-M3 were from 70 to 230, while the granularity of DPSC-M3 were from 30 to 220. The size and granularity of DPSC-M3 are slightly different when compared with other MSCs obtained from various tissues, like bone marrow and wharton's jelly (WJMSC). ${ }^{22,23}$ Several researches stated that cells with smaller size have higher proliferation ability, expressed more MSC marker, and expressed less senescence-associated marker expression. ${ }^{22,23}$ Compared with DPSC-M3, the size and granularity of WJ-MSC are smaller, suggesting that WJMSC is more pluripotent than DPSC-M3.

Current results of cell surface antigens examination showed that CD90, CD105 and CD73 were highly expressed (>95\%), meanwhile expressions of CD45, CD34, CD11b, CD19 and HLA-DR were $<2 \%$. These results suggest that the examined DPSC-M3 is an MSC. Previously, dental pulp of third molars had been been reported. ${ }^{24}$ It was termed as human tooth germ stem cells (hTGSCs) and characterized positive for CD73, CD90, CD105 and CD166, but negative for CD34, CD45 and CD133. ${ }^{24}$ The hTGSCs were suggested as mesenchymallike stem cells. The markers were almost the same with slight differences for CD166, CD133, CD11b, CD19 and HLA-DR. Both DPSC-M3 and hTGSCs were cultured in the same condition, suggesting that both DPSC-M3 and hTGSCs were similar.

There are some potential usages of DPSC-M3, one of them is the regenerative treatment in dentistry. ${ }^{13}$ Besides that, stem cell exosomes could be useful to induce surrounding normal cell growth ${ }^{25}$ and to inhibit tumor cell growth ${ }^{10}$. For tissue regenerative treatment purposes, high number of stem cell is necessary. ${ }^{26}$ Since number of isolated DPSC-M3 was low, DPSC-M3 should be propagated to reach optimal cell number. Several approaches have been reported showing that stem cell proliferation could be induced with supplements/growth factors ${ }^{27-29}$ and herbal $\operatorname{extracts}^{30-32}$. Hence, this study should be explored to enhance the development in DPSC. 

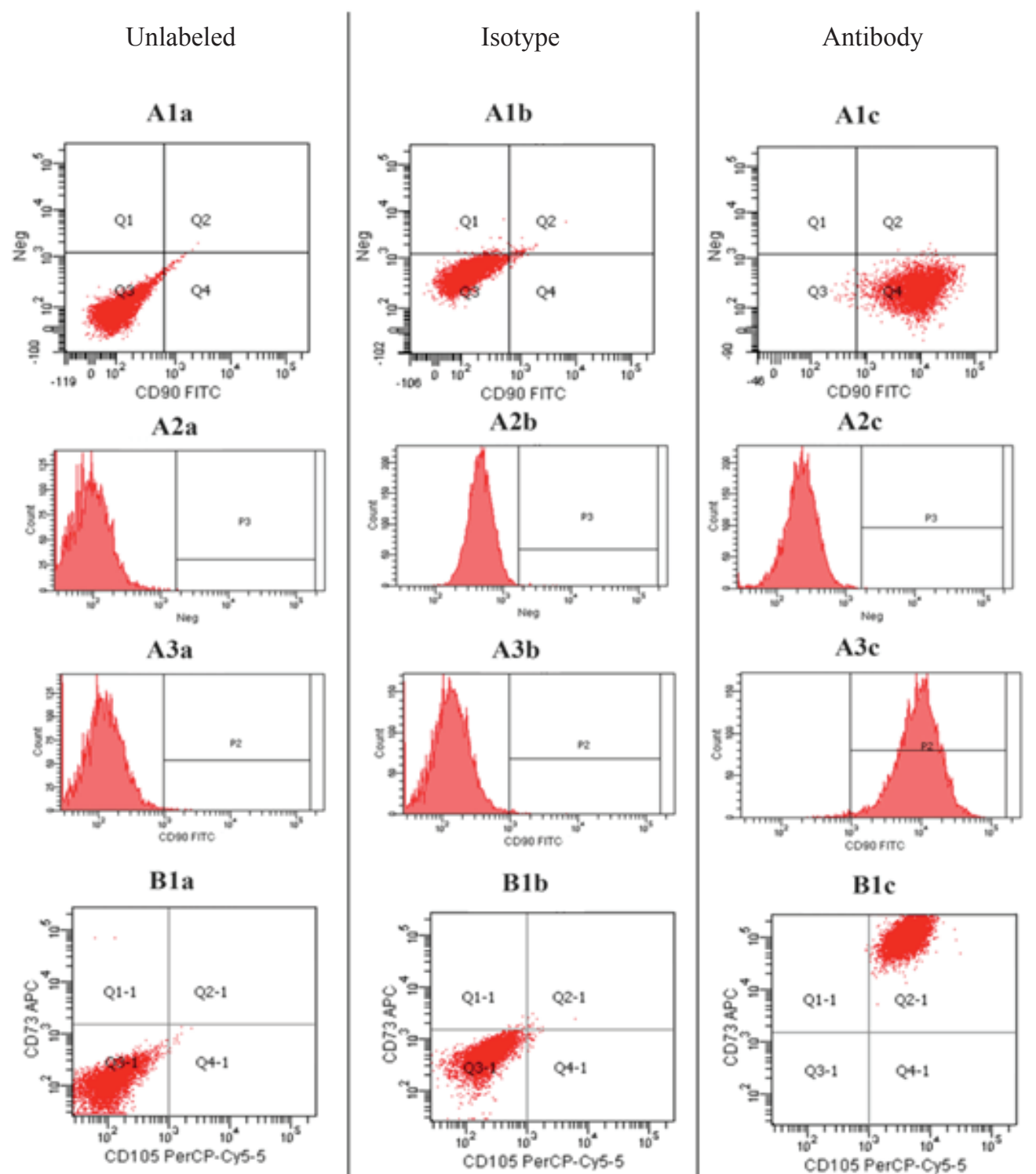

\section{B1b}

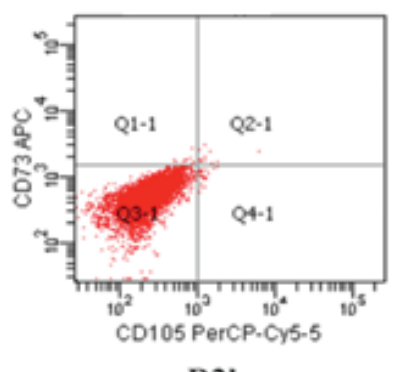

B1c

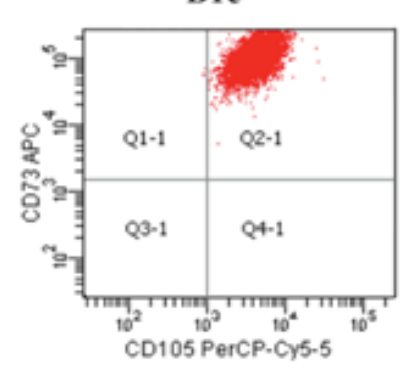

B2b
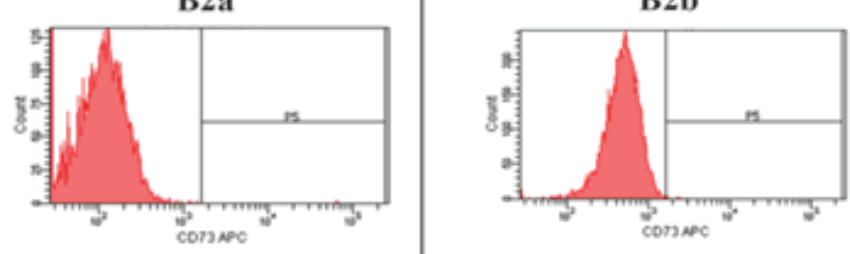

B2c

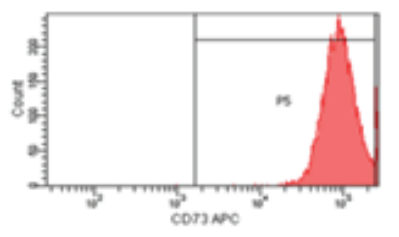

B3a
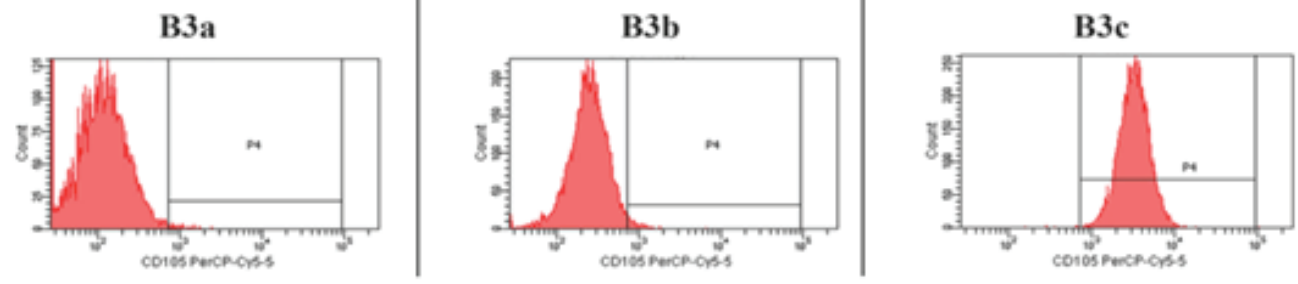

Figure 2. Dot plot and histogram results of DPSC-M3. DPSC-M3 in passage 5 was harvested and labeled with antibodies for negative markers (CD45, CD34, CD11b, CD19 and HLA-DR) and CD90 isotype antibody (A1b) or CD90 antibody (A1c). DPSC-M3 was also labeled with CD73 and CD105 isotype antibodies (B1b) or with CD73 and CD105 antibodies (B1c). The examination was conducted three times. A1a and B1a: unlabeled DPSC. A2a-c: histograms for negative markers of A1a-c, respectively. A3a-c: histograms for CD90 of A1a-c, respectively. B2a-c: histograms for CD73 of B1a-c, respectively. B3a-c: histograms for CD105 of B1a-c, respectively. Neg: negative markers. 
Table 1. The percentage of negative markers and CD90. Group and gated areas were correlated with dot plot and histogram results of Figure 2. The examination was conducted three times.

\begin{tabular}{|c|c|c|c|c|c|c|c|}
\hline \multirow{2}{*}{ Group } & \multirow{2}{*}{ Unit } & \multicolumn{6}{|c|}{ Gated Areas (\%) } \\
\hline & & Q1 & Q2 & Q3 & Q4 & P2 & P3 \\
\hline Unlabeled & 1 & 0 & 0.2 & 98.6 & 1.2 & 0.4 & 0.1 \\
\hline \multirow[t]{2}{*}{ (A1a, A2a and A3a) } & 2 & 0 & 0 & 99.0 & 1.0 & 0.3 & 0 \\
\hline & 3 & 0 & 0.1 & 98.8 & 1.1 & 0.5 & 0 \\
\hline Isotype Antibodies-labeled & 1 & 1 & 0.9 & 97.3 & 0.8 & 0.5 & 0.2 \\
\hline \multirow[t]{2}{*}{ (A1b, A2b and A3b) } & 2 & 0.7 & 0.7 & 98.0 & 0.6 & 0.4 & 0.1 \\
\hline & 3 & 0.5 & 1.0 & 87.8 & 0.7 & 0.6 & 0.3 \\
\hline Antibodies-labeled & 1 & 0 & 0.3 & 0.5 & 99.2 & 97 & 0.1 \\
\hline \multirow[t]{2}{*}{ (A1c, A2c and A3c) } & 2 & 0 & 0.5 & 0.4 & 99.1 & 97.2 & 0 \\
\hline & 3 & 0 & 0.1 & 0.3 & 99.6 & 97 & 0 \\
\hline
\end{tabular}

Table 2. The percentage of CD73 and CD105. Group and gated areas were correlated with dot plot and histogram results of Figure 2.The examination was conducted three times.

\begin{tabular}{lrrrrrrrr}
\hline \multirow{2}{*}{ Group } & Unit & \multicolumn{7}{c}{ Gated Areas (\%) } \\
\cline { 3 - 8 } & & Q1-1 & Q2-1 & Q3-1 & Q4-1 & P4 & P5 \\
\hline Unlabeled & 1 & 0.1 & 0 & 99.5 & 0.4 & 0.6 & 0 \\
(B1a, B2a and B3a) & 2 & 0 & 0 & 99.7 & 0.3 & 0.4 & 0 \\
& 3 & 0 & 0 & 99.4 & 0.6 & 0.8 & 0 \\
\hline Isotype Antibodies-labeled & 1 & 0.3 & 0.3 & 98.5 & 0.9 & 1.7 & 0.3 \\
(B1b, B2b and B3b) & 2 & 0.2 & 0.2 & 99.0 & 0.6 & 1.6 & 0.1 \\
& 3 & 0.4 & 0.5 & 98.1 & 1.0 & 1.9 & 0.4 \\
\hline Antibodies-labeled & 1 & 0.1 & 99.9 & 0 & 0 & 98.8 & 99.0 \\
(B1c, B2c and B3c) & 2 & 0 & 100.0 & 0 & 0 & 97.6 & 99.2 \\
& 3 & 0.3 & 99.7 & 0 & 0 & 97.0 & 98.7 \\
\hline
\end{tabular}

\section{Conclusion}

Since CD73, CD90 and CD105 were positively expressed, meanwhile CD34, CD45, CD11b, CD19 and HLA-DR were negatively expressed, therefore DPSC-M3 could be suggested as an MSC.

\section{References}

1. Sjamsuhidajat, Sandra F, Tarwadi, Sardjono CT, Widyawati H, Ismail, et al. Pedoman Riset Sel Punca Manusia. Jakarta: Asosiasi Sel Punca Indonesia; 2010.

2. Sandra F, Sidiq KM, Halim D. Terapi Stem Cell - Terobosan Kedokteran Modern untuk Penderita Gagal Jantung. Jakarta: Grasindo; 2012.

3. Halim D, Murti H, Sandra F, Boediono A, Djuwantono T, Setiawan B. Stem Cell Dasar Teori \& Aplikasi Klinis. Jakarta: Penerbit Erlangga; 2010.
4. Chalisserry EP, Nam SY, Park SH, Anil S. Therapeutic Potential of Dental Stem Cells. J Tissue Eng. 2017; 8: 2041731417702531.

5. Mao X, Liu Y, Chen C. Mesenchymal Stem Cells and Their Role in Dental Medicine. Dent Clin NA. 2017; 61(1): 161-72.

6. Potdar PD, Jethmalani YD. Human Dental Pulp Stem Cells: Applications in Future Regenerative Medicine. World J Stem Cells. 2015; 7(5): 839-51.

7. Aini N, Setiawan B, Sandra F. Karakteristik Biologis dan Diferensiasi Stem Cell: Fokus pada Mesenchymal Stem Cell. CDK. 2008; 35(161): 64-7.

8. Ryan JM, Barry FP, Murphy JM, Mahon BP. Mesenchymal Stem Cells Avoid Allogeneic Rejection. J Inflamm. 2005; 2(1): 8. doi: 10.1186/1476-9255-2-8

9. Widowati W, Sardjono CT, Wijaya L, Laksmitawati DR, Sandra F. Extract of Curcuma longa L. and (-)-Epigallo Catechin-3-Gallate Enhanced Proliferation of Adipose Tissue-derived Mesenchymal Stem Cells (AD-MSCs) and Differentiation of AD-MSCs into Endothelial Progenitor Cells. J USA-China Med Sci. 2012; 9(1): 22-9. 
10. Sandra F, Sudiono J, Sidharta EA, Sunata EP, Sungkono DJ, Dirgantara Y, Chouw A. Conditioned Media of Human Umbilical Cord Blood Mesenchymal Stem Cell-derived Secretome Induced Apoptosis and Inhibited Growth of HeLa Cells. Indones Biomed J. 2014; 6(1): 57-62.

11. Lubis AM, Sandhow L, Lubis VK, Noor A, Gumay F, Merlina M, et al. Isolation and Cultivation of Mesenchymal Stem Cells from Iliac Crest Bone Marrow for Further Cartilage Defect Management. Acta Med Indones. 2011; 43(3): 178-84

12. Hass R, Kasper C, Böhm S, Jacobs R. Different Populations and Sources of Human Mesenchymal Stem Cells (MSC): A Comparison of Adult and Neonatal Tissue-derived MSC. Cell Commun Signal. 2011; 9(1): 12. doi: 10.1186/1478-811X-9-12.

13. Sudiono J, Oka CT, Djamil MS, Sandra F. Regenerative Medicine in Dental and Oral Tissues: Dental Pulp Mesenchymal Stem Cell. Padjadjaran J Dent. 2016; 28(1): 31-7.

14. Yu T, Volponi AA, Babb R, An Z, Sharpe PT. Stem Cells in Tooth Development, Growth, Repair, and Regeneration. Curr Top Dev Biol. 2015; 115: 187-212.

15. Ledesma-martínez E, Mendoza-núñez VM. Mesenchymal Stem Cells Derived from Dental Pulp: A Review. Stem Cells Int. 2016; 2016: 4709572. doi: 10.1155/2016/4709572.

16. Alge DL, Zhou D, Adams LL, Wyss BK, Shadday MD, Woods EJ, et al. Donor-matched Comparison of Dental Pulp Stem Cells and Bone Marrowderived Mesenchymal Stem Cells in A Rat Model. J Tissue Eng Regen Med. 2010; 4(1): 73-81.

17. Atalayin C, Tezel H, Dagci T, Karabay Yavasoglu NU, Oktem G, Kose T. In vivo Performance of Different Scaffolds for Dental Pulp Stem Cells Induced for Odontogenic Differentiation. Braz Oral Res. 2016; 30(1): e120. doi: 10.1590/1807-3107BOR-2016.vol30.0120.

18. Bakopoulou A, About I. Stem Cells of Dental Origin: Current Research Trends and Key Milestones towards Clinical Application. Stem Cells Int. 2016; 2016: 4209891. doi: 10.1155/2016/4209891.

19. Feter Y, Afiana NS, Chandra JN, Abdullah K, Shafira J, Sandra F. Dental Mesenchymal Stem Cell: Its Role in Tooth Development, Types, Surface Antigens and Differentiation Potential. Mol Cell Biomed Sci. 2017; 1(2): 50-7.

20. Dominici M, Le Blanc K, Mueller I, Slaper-Cortenbach I, Marini F, Krause D, et al. Minimal Criteria for Defining Multipotent Mesenchymal Stromal Cells. The International Society for Cellular Therapy Position Statement. Cytotherapy. 2006; 8(4): 315-7.

21. Sandra F, Sudiono J, Tri C, Binartha O, Chouw A, Djamil MS, Growth and Osteogenic Differentiation of CD117+ Dental Pulp and Periodontal Ligament Cells. Indones Biomed J. 2017; 9(2): 78-83.
22. Majore I, Moretti P, Hass R, Kasper C. Identification of Subpopulations in Mesenchymal Stem Cell-like Cultures from Human Umbilical Cord. Cell Commun Signal. 2009; 7: 6. doi: 10.1186/1478-811X-7-6.

23. Madeira A, Silva CLD, Santos FD, Camafeita E, Cabral JMS, Correia IS. Human Mesenchymal Stem Cell Expression Program upon Extended ex-vivo Cultivation, as Revealed by 2-DE-based Quantitative Proteomics. PLOS ONE. 2012; 7(8): e43523. doi: 10.1371/journal.pone.0043523.

24. Yalvac ME, Ramazanoglu M, Rizvanov AA, Sahin F, Bayrak OF, Salli $\mathrm{U}$, et al. Isolation and Characterization of Stem Cells Derived from Human Third Molar Tooth Germs of Young Adults: Implications in Neo-vascularization, Osteo-, Adipo- and Neurogenesis. Pharmacogenomics J. 2010; 10(2): 105-13.

25. Sandra F, Lahirin R. Human Umbilical Cord Blood Serum Has Higher Potential in Inducing Proliferation of Fibroblast than Fetal Bovine Serum. Mol Cell Biomed Sci. 2017; 1(2): 65-9.

26. Sandra F, Murti H, Aini N, Sardjono C, Setiawan B. Potensi Terapi Sel Punca dalam Dunia Kedokteran dan Permasalahannya. JKM. 2008; 8(1): 94-101.

27. Oktaviono YH, Sargowo D, Widodo MA, Dirgantara Y, Chouw A, Sandra F. Proliferation of Peripheral Blood-derived Endothelial Progenitor Cells from Stable Angina Subjects. Indones Biomed J. 2014; 6(2): 91-6.

28. Sandra F, Oktaviono YH, Widodo MA, Dirgantara Y, Chouw A, Sargowo D. Endothelial Progenitor Cells Proliferated via MEKdependent p42 MAPK Signaling Pathway. Mol Cell Biochem. 2015; 400(1-2): 201-6.

29. Oktaviono YH, Sargowo D, Widodo MA, Dirgantara Y, Chouw A, Sandra F. Role of Signal Transduction Erk1/2 on The Proliferation of Endothelial Progenitor Cell (EPC) of Patients with Stable Angina Pectoris Induced by Growth Factors. Indones J Clin Pathol Med Lab. 2016; 22(3): 219-26.

30. Widowati W, Mozef T, Risdian C, Ratnawati H, Tjahjani S, Sandra F. The Comparison of Antioxidative and Proliferation Inhibitor Properties of Piper betle L., Catharanthus roseus [L] G.Don, Dendrophtoe petandra L., Curcuma mangga Val. Extracts on T47D Cancer Cell Line. Int Res J Biochem Bioinform. 2011; 1(2): 22-8.

31. Sandra F, Munir D. Herbal medicine induces circulation and proliferation of Endothelial Progenitor Cell (EPC). Stem Cell Oncology. 2018; 2018: 103-7.

32. Sandra F. Role of Herbal Extract in Stem Cell Development. Mol Cell Biomed Sci. 2018; 2(1): 19-22. 